\title{
KONTRIBUSI USAHA AGROINDUSTRI TAHU TERHADAP PENDAPATAN RUMAH TANGGA SELAMA MASA PANDEMI COVID-19 DI DESA KALISARI KECAMATAN CILONGOK
}

\author{
Tika Yuaningsih \\ Email: tikayuaningsih@yahoo.com \\ Program Studi Agribisnis Universitas Muhammadiyah Purwokerto \\ Jl. KH. Ahmad Dahlan Purwokerto \\ Pujiharto \\ Email: p_harto@yahoo.co.id \\ Program Studi Agribisnis Universitas Muhammadiyah Purwokerto \\ J1. KH. Ahmad Dahlan Purwokerto \\ Watemin \\ Email: watemyn@ump.ac.id \\ Program Studi Agribisnis Universitas Muhammadiyah Purwokerto \\ Jl. KH. Ahmad Dahlan Purwokerto
}

\begin{abstract}
ABSTRAK
Pandemi covid-19 menyebabkan berbagai usaha mengalami banyak penurunan bahkan sampai mengalami kerugian. Berbagai cara dilakukan oleh para pengusaha untuk menyelamatkan usahanya dari kebangkrutan. Penelitian ini bertujuan untuk mengetahui biaya dan pendapatan, kelayakan usaha, serta kontribusi usaha agroindustri tahu terhadap pendapatan rumah tangga di Desa Kalisari Kecamatan Cilongok Kabupaten Banyumas sebelum dan selama masa pandemi covid19. Metode yang digunakan dalam penelitian ini adalah deskriptif kuantitatif. Teknik pengambilan sampel yang digunakan adalah simple random sampling dengan menggunakan rumus Slovin. Hasil penelitian menunjukkan biaya rata-rata yang dikeluarkan sebelum masa pandemi sebesar Rp.13.694.321 per bulan dan pada masa pandemi covid-19 sebesar Rp.11.857.403 per bulan. Pendapatan yang diperoleh dari usaha agroindustri tahu pada masa sebelum pandemi covid-19 ratarata sebesar Rp.7.807.399 per bulan dan selama masa pandemi covid-19 turun menjadi Rp.6.560.997 per bulan. Kelayakan usaha agroindustri tahu baik sebelum dan selama masa pandemi covid-19 layak untuk diusahakan. Sementara kontribusi usaha agroindustri tahu sebelum dan selama masa pandemi covid-19 memberikan kontribusi yang tinggi terhadap pendapatan rumah tangga pengrajin tahu.
\end{abstract}

Kata Kunci: agroindustri tahu, kelayakan usaha, kontribusi pendapatan

\begin{abstract}
Pandemic covid-19 has caused various businesses to experience a lot of decline, even to the point of experiencing losses. Various methods are used by entrepreneurs to save their business from losses. This study aims to determine costs and income, business feasibility, and the contribution of tofu agro-industry to household income in Kalisari Village, Cilongok District, Banyumas Regency before and during the covid-19 pandemic. The method used in this research is descriptive quantitative. The sampling technique used was simple random sampling using the Slovin formula. The results showed that the average cost before the pandemic was IDR 13,694,321 per month and during the covid-19 pandemic, it was IDR 11,857,403 per month. The income obtained from the tofu agro-industry business before the Covid-19 pandemic was an average of IDR 7,807,399 per month and during the covid-19 pandemic period it decreased to IDR 6,560,997 per month. The feasibility of tofu agroindustry both before and during the covid-19 pandemic is feasible. Meanwhile, the contribution of the tofu agroindustry before and during the covid-19 pandemic made a high contribution to the household income of tofu craftsmen.
\end{abstract}

Keywords: agroindustry, feasibility, income contribution 


\section{PENDAHULUAN}

Agribisnis adalah setiap usaha yang berkaitan dengan kegiatan produksi pertanian, yang meliputi pengusahaan input pertanian, dan atau pengusahaan produksi itu sendiri atau pun juga pengusahaan pengelolaan hasil pertanian (Sjarkowi \& Sufri, 2004). Dalam agribisnis terdapat agroindustri yang kegiatan usahanya menggunakan hasil pertanian sebagai input atau industri pengolahan hasil pertanian dan perdagangan. Pengembangan agroindustri di tanah air ini merupakan suatu keharusan dalam rangka menuju masyarakat industri yang berbasis pada pertanian. Hal ini disebabkan karena sektor industri sangat menguntungkan bagi kehidupan mayoritas masyarakat pedesaan. Sebagian besar penduduk Indonesia berdomisili di pedesaan, untuk itu pembangunan ekonomi masyarakat sebagai satu kesatuan antara pembangunan sektor pertanian dan industri kecil diarahkan pada upaya pemberdayaan agroindustri. Saat ini minat dan perhatian terhadap pengembangan industri pedesaan maupun industri kecil secara umum terus meningkat. Kemampuannya dalam menampung tenaga kerja maupun memberikan pendapatan bagi masyarakat pedesaan, dan terlebih pada akhir-akhir ini dimana kesempatan kerja pertanian masih terbatas, telah menempatkan kegiatan industri kecil dan industri rumah tangga sebagai bagian yang tidak terpisahkan dari ekonomi pedesaan. Menurut (Udayana, (2011), dalam kerangka pembangunan pertanian peran agroindustri sebagai leading sector sangat besar. Peran ini dalam rangka mewujudkan sektor pertanian yang tangguh, maju dan efisien. Strategi pengembangan agroindustri harus disesuaikan dengan karakteristik dan permasalahan yang dihadapi oleh agroindustri tersebut.

Tahun 2020 baru berjalan tiga bulan, namun goncangan ekonomi telah terjadi. Ekonomi tiba-tiba ambruk dalam sekejap akibat menyebarnya virus Covid-19 hingga ke seluruh dunia. Akibat adanya pandemi covid-19 wilayah-wilayah desa, kota dan bahkan negara melakukan penutupan. Tidak ada lalu lintas dan aktifitas normal seperti beberapa waktu sebelumnya. Krisis pandemi covid-19 bukan hanya tentang krisis kesehatan saja, tetapi juga krisis ekonomi. Itu sebabnya krisis ini memberikan dampak pada seluruh sektor hulu dan industri hilir. Dampak pandemi covid-19 secara makro adalah kerugian ekonomi secara nasional. Hasil kajian (Hadiwardoyo, 2020) kerugian ekonomi secara nasional meliputi penurunan PDB per kapita dan menurunnya pertumbuhan ekonomi secara signifikan. 
Pada skala mikro, salah satu sektor industri pedesaan yang terdampak akibat adanya pandemi covid-19 saat ini yaitu agroindustri tahu di Desa Kalisari Kecamatan Cilongok. Desa Kalisari adalah desa dimana penduduknya banyak yang mengusahakan agroindustri tahu. Tahu merupakan salah satu produk dari industri yang berasal dari bahan baku kedelai. Menurut data Monografi Desa Kalisari tahun 2019, Desa Kalisari merupakan daerah sentra industri tahu dengan jumlah pengrajin tahu sebanyak 251 pengrajin tahu. Jenis tahu yang diproduksi oleh pengrajin tahu di Desa Kalisari Kecamatan Cilongok yaitu tahu kuning, tahu cokelat (matang), dan tahu bolo (Anonim, 2019). Berdasarkan data tersebut maka penelitian ini ingin mengkaji bagaimana biaya dan pendapatan, kelayakan serta kontribusi usaha agroindustri tahu terhadap pendapatan rumah tangga pengrajin.

\section{METODE PENELITIAN}

Metode penelitian yang digunakan yaitu menggunakan metode deskriptif kuantitatif. Penelitian deskriptif adalah metode penelitian yang digunakan untuk menemukan pengetahuan yang seluas-luasnya terhadap objek penelitian pada suatu masa tertentu (Alimul, 2010) dan penelitian kuantitatif adalah penelitian dengan memperoleh data yang berbentuk angka atau data kualitatif yang diangkakan (Sugiyono, 2003).

Populasi dalam penelitian ini pengrajin agroindustri tahu di Desa Kalisari Kecamatan Cilongok. Penentuan sampel menggunakan sampel acak sederhana (simple random sampling). Menurut (Bungin, 2005), simple random sampling adalah cara pengambilan sampel dari anggota populasi dengan menggunakan acak tanpa memperhatikan strata (tingkatan) dalam anggota populasi tersebut. Teknik tersebut dilakukan apabila populasi dianggap homogen (sejenis) dalam jenis usahanya dan produk yang dihasilkan (Riduwan, 2006). Jumlah pengrajin tahu di Desa Kalisari berjumlah 251 pengrajin. Selanjutnya jumlah sampel dihitung dengan menggunakan rumus Slovin dengan tingkat kesalahan sebesar 5\% sehingga diperoleh sampel sebanyak 154 responden.

Untuk mengetahui pendapatan agroindustri tahu Desa Kalisari Kecamatan Cilongok menggunakan analisis pendapatan (Soekartawi, 1995):

$$
\mathrm{Y}=\mathrm{TR}-\mathrm{TC}
$$

Keterangan:

$$
\begin{aligned}
& \mathrm{Y}=\text { pendapatan agroindustri tahu Desa Kalisari Kecamatan Cilongok (Rp) } \\
& \mathrm{TR}=\text { total penerimaan agroindustri tahu Desa Kalisari Kecamatan Cilongok (Rp) } \\
& \mathrm{TC}=\text { total biaya agroindustri tahu Desa Kalisari Kecamatan Cilongok (Rp) }
\end{aligned}
$$


Untuk mengetahui kelayakan usaha agroindustri tahu Desa Kalisari Kecamatan Cilongok menggunakan analisis kelayakan usaha (Soekartawi, 2006):

Revenue Cost Ratio $(\mathrm{R} / \mathrm{C})=\frac{\mathrm{TR}}{\mathrm{TC}}$

Keterangan:

$\mathrm{TR}=$ total penerimaan agroindustri tahu Desa Kalisari Kecamatan Cilongok $(\mathrm{Rp})$

$\mathrm{TC}=$ total biaya agroindustri tahu Desa Kalisari Kecamatan Cilongok (Rp)

Adapun kriteria kelayakan adalah sebagai berikut:

- $\quad \mathrm{R} / \mathrm{C}$ ratio $\leq 1$, maka agroindustri tahu tidak layak untuk dikembangkan

- $\quad \mathrm{R} / \mathrm{C}$ ratio $=1$, maka agroindustri tahu berada dititik impas (tidak mengalami untung dan tidak rugi)

- $\quad \mathrm{R} / \mathrm{C}$ ratio $\geq 1$, maka agroindustri tahu layak untuk dikembangkan.

Sedangkan untuk mengetahui kontribusi usaha agroindustri tahu Desa Kalisari Kecamatan Cilongok terhadap pendapatan total rumah tangga digunakan persentase kontribusi dengan rumus (Hasib, 2004):

$$
\mathrm{Z}=\frac{A}{B} \times 100 \%
$$

Keterangan:

$\mathrm{Z}=$ kontribusi pendapatan agroindustri tahu terhadap pendapatan total keluarga (\%)

$\mathrm{A}=$ pendapatan agroindustri tahu $(\mathrm{Rp} / \mathrm{bulan})$

$\mathrm{B}=$ pendapatan total rumah tangga pemilik agroindustri (Rp/bulan)

Menurut Kumala (2011), besarnya kontribusi suatu usaha terhadap pendapatan total keluarga dapat diklasifikasikan sebagai berikut:

- $\mathrm{Z} \leq 33,3 \%$ maka kontribusi pendapatan agroindustri tahu terhadap pendapatan total rumah tangga tergolong rendah

- 33,4\% $<\mathrm{Z} \leq 66,6 \%$ maka kontribusi pendapatan agroindustri tahu terhadap pendapatan total rumahtangga tergolong sedang

- $Z>66,7 \%$ maka kontribusi pendapatan agroindustri tahu terhadap pendapatan total rumah tangga tergolong tinggi. 


\section{HASIL DAN PEMBAHASAN}

\section{Hasil}

\section{a. Biaya dan Pendapatan Usaha Agroindustri Tahu}

Usaha agroindustri tahu memerlukan biaya yang terdiri dari biaya tetap dan biaya variabel. Adapun biaya yang diperlukan untuk menjalankan usaha agroindustri tahu di Desa Kalisari Kecamatan Cilongok adalah sebagai berikut.

Tabel 1. Rata-rata Biaya Usaha Agroindustri Tahu di Desa Kalisari Kecamatan Cilongok (rupiah/bulan)

\begin{tabular}{lcc}
\hline Komponen Biaya & Sebelum Pandemi & Selama Pandemi \\
\hline Biaya Tetap & 31.011 & 31.011 \\
Biaya Variabel & & \\
- Bahan baku kedelai & 9.926 .580 & 8.630 .856 \\
- Kunyit & 117.030 & 90.402 \\
- Garam & 192.330 & 140.686 \\
- Air & 20.000 & 20.000 \\
- Kayu bakar & 677.050 & 578.422 \\
- Tenaga kerja & 2.730 .330 & 2.366 .286 \\
\hline Total Biaya & 13.694 .321 & 11.857 .403 \\
\hline Total Penerimaan & 21.501 .720 & 18.418 .400 \\
\hline Total Keuntungan & $\mathbf{7 . 8 0 7 . 3 9 9}$ & $\mathbf{6 . 5 6 0 . 9 9 7}$ \\
\hline
\end{tabular}

Sumber: Data Primer, 2020.

Dari tabel 1 diketahui bahwa rata-rata total biaya usaha agroindustri tahu mengalami penurunan pada masa pandemi dibandingkan dengan masa sebelum pandemi. Demikian juga dengan rata-rata penerimaan dari usaha agroindustri tahu rata-rata mengalami penurunan sehingga rata-rata keuntungan usaha agroindustri tahu mengalami penurunan selama masa pandemi dibandingkan dengan sebelum pandemi.

\section{b. Kelayakan Usaha Agroindustri Tahu}

Untuk menilai kelayakan usaha agroindustri tahu di Desa Kalisari Kecamatan Cilongok adalah dengan membandingkan antara total penerimaan dengan total biaya usaha yang telah dikeluarkan. Kelayakan usaha agroindustri tahu di Desa Kalisari Kecamatan Cilongok adalah sebagai berikut.

Tabel 2. Kelayakan Usaha Agroindustri Tahu di Desa Kalisari Kecamatan Cilongok

\begin{tabular}{lcc}
\hline Komponen Perhitungan & Sebelum Pandemi & Selama Pandemi \\
\hline Total Biaya & 13.694 .321 & 11.857 .403 \\
Total Penerimaan & 21.501 .720 & 18.418 .400 \\
\hline R/C ratio & $\mathbf{1 , 5 7}$ & $\mathbf{1 , 5 5}$ \\
\hline
\end{tabular}

Sumber: Data Primer, 2020. 
Dari tabel 2 diketahui bahwa kelayakan usaha agroindustri tahu di Desa Kalisari Kecamatan Cilongok mengalami penurunan selama masa pandemi, walaupun masih feasible untuk tetap diusahakan.

\section{c. Kontribusi Usaha Agroindustri terhadap Pendapatan Rumah Tangga}

Kontribusi usaha agroindustri tahu terhadap total pendapatan rumah tangga di Desa Kalisari Kecamatan Cilongok dapat dilihat pada tabel 3 berikut.

Tabel 3. Kontribusi Usaha Agroindustri Tahu terhadap Pendapatan Rumah Tangga di Desa Kalisari Kecamatan Cilongok

\begin{tabular}{lc}
\hline Keterangan & Kontribusi \\
\hline Sebelum pandemi covid-19 & $99,16 \%$ \\
Selama pandemi covid-19 & $98,97 \%$ \\
\hline
\end{tabular}

Sumber: Data Primer, 2020.

Dari data tabel 3 terlihat bahwa kontribusi usaha agroindustri tahu di Desa Kalisari Kecamatan Cilongok tergolong dalam kategori tinggi, namun demikian kontribusi tersebut mengalami penurunan selama masa pandemi covid-19. Penurunan kontribusi pendapatan diakibatkan karena adanya penurunan keuntungan yang diperoleh para pengrajin tahu.

\section{Pembahasan}

Biaya usaha agroindustri tahu di Desa Kalisari yang paling banyak dikeluarkan adalah untuk biaya pembelian bahan baku utama berupa kedelai. Dampak dari pandemi covid-19 adalah harga bahan baku kedelai mengalami peningkatan. Hal ini mengingat kedelai termasuk ke dalam bahan untuk menopang ketahanan pangan yang sangat terpengaruh rantai pasoknya (Hirawan \& Verselita, 2020). Kenaikan harga bahan baku kedelai akan memberikan dampak meningkatnya biaya yang harus ditanggung oleh para pengrajin agroindustri tahu. Dampak lain akibat pandemi covid-19 adalah adanya kebijakan pemerintah dalam hal pembatasan sosial. Kebijakan ini membuat banyak warga untuk lebih banyak berada di rumah atau membatasi untuk melakukan aktivitas di luar rumah. Dampak yang dirasakan oleh para pengrajin adalah berkurang pembelian produk tahu oleh konsumen.

Kondisi pandemi covid-19 berpengaruh terhadap pengrajin tahu di Desa Kalisari dalam memproduksi tahu karena bahan baku kedelai naik dan permintaan konsumen juga menurun. Pada kondisi sebelum pandami covid-19 harga bahan baku kedelai Rp.7.400 per kilogram, tetapi pada masa pandemi covid-19 harga bahan baku kedelai mengalami peningkatan yaitu mencapai harga Rp.7.800 per kilogramnya. Naiknya harga bahan baku kedelai mengakibatkan para pengrajin tahu harus berfikir bagaimana cara untuk tetap 
memproduksi tahu agar memperoleh pendapatan. Cara yang dilakukan oleh para pengrajin tahu agar tetap memproduksi tahu dan memperoleh pendapatan yaitu dengan cara mengurangi jumlah produksi tahu dan memperkecil ukuran potongan tahu dari biasanya. Dengan cara tersebut, para pengrajin tahu di Desa Kalisari tetap akan memperoleh pendapatan, walaupun pada akhirnya jumlah pendapatan yang diterima akan mengalami penurunan. Penurunan pendapatan yang dialami oleh para pengrajin usaha agroindustri tahu di Desa Kalisari Kecamatan Cilongok sebesar 15,96\% dibandingkan dengan masa sebelum pandemi berlangsung. Hasil ini sejalan dengan penelitian yang dilakukan oleh (Ferdi, 2020) yang menyimpulkan bahwa dampak dari pandemi covid-19 adalah pendapatan masyarakat (pedagang, nelayan dan petani) semakin menurun, banyak fasilitas (umum) ekonomi yang ditutup, ekonomi masyarakat dan wilayah semakin menurun, harga pasaran hasil bumi turun, dan kebutuhan pokok semakin melonjak. Sementara penelitian yang dilakukan oleh (Kurniasih, 2020) mengenai dampak pandemi covid-19 terhadap penurunan kesejahteraan masyarakat Kota Pontianak menyebutkan bahwa telah terjadi penurunan kesejahteraan masyarakat akibat penurunan pendapatan sebesar $30-70 \%$ sementara pengeluaran masyarakat tetap. Akan tetapi hasil penelitian (Sarni \& Sidayat, 2020) menyebutkan bahwa telah terjadi penurunan pendapatan petani sayuran kangkung selama pandemi covid-19, akan tetapi petani cabai mengalami peningkatan pendapatan selama masa pandemi covid-19, sementara petani terung tingkat pendapatannya stabil.

Berdasarkan kelayakannya, usaha agroindustri tahu di Desa Kalisari Kecamatan Cilongok adalah layak untuk diusahakan baik sebelum maupun selama masa pandemi covid-19. Selama masa pandemi covid-19, kelayakan usaha agroindustri tahu di Desa Kalisari Kecamatan Cilongok mengalami penurunan sebesar 1,27 \%. Penurunan kelayakan usaha disebabkan karena naiknya harga kedelai sebagai bahan baku utama agroindustri tahu. Kenaikan harga kedelai tidak saja terjadi di dalam negeri saja, akan tetapi juga dipasaran internasional. Berdasarkan data yang dikeluarkan oleh The Food and Agriculture Organization (FAO), harga rata-rata kedelai pada Desember 2020 sebesar US\$461 per ton, yang mengalami kenaikan sebesar 6\% dibandingkan bulan sebelumnya yaitu sebesar US\$435 per ton, (Prakoso, 2021). Salah satu faktor utama penyebab naiknya harga kedelai dunia adalah meingkatnya permintaan kedelai dari China kepada Amerika Serikat selaku eksportir kedelai terbesar di dunia. Permintaan kedelai China mengalami kenaikan dari 15 juta ton menjadi 30 juta ton. Akibat kenaikan harga kedelai sebagai bahan baku utama 
agroindustri tahu menyebabkan para pengusaha mengurangi jumlah produksinya sehingga secara keseluruhan kelayakan usaha agroindustri tahu mengalami penurunan.

Kontribusi pendapatan agroindustri tahu terhadap pendapatan rumah tangga di Desa Kalisari Kecamatan Cilongok pada masa sebelum pandemi covid-19 sebesar 99,16\% dan selama masa pandemi covid-19 sebesar 98,97\%. Kontribusi ini tergolong tinggi. Tingkat kontribusi agroindustri tahu yang tinggi di Desa Kalisari Kecamatan Cilongok tergolong tinggi karena usaha agroindustri tahu merupakan sumber pendapatan utama para pengrajin tahu. Usaha agroindustri di Desa Kalisari Kecamatan Cilongok sudah lama diusahakan dan bahkan sudah turun temurun sehingga menjadi mata pencaharian utama. Kondisi ini sejalan hasil penelitian (Setiawati et al., 2013) tentang kontribusi agroindustri dawet ireng terhadap pendapatan rumah tangga di Kecamatan Butuh Purworejo. Hasil ini penelitian tersebut menjelaskan bahwa usaha agroindustri dawet ireng memberikan kontribusi tinggi (70,68\%). Hasil penelitian ini menjelaskan juga bahwa agroindustri dawet ireng yang ada di Kecamatan Butuh Purworejo menjadi sumber penghasilan utama bagi rumah tangga. Demikian juga hasil penelitian (Noor et al., 2019) mengenai kontribusi pendapatan pekerja usaha tahu nipon terhadap pendapatan keluarga di Desa Tateli Kecamatan Mandolang. Hasil penelitian ini menjelaskan bahwa kontribusi pendapatan pekerja usaha tahu nipon terhadap pendapatan keluarga sebesar 83,33\%, yang berarti tergolong tinggi. Hasil penelitian ini juga menyebutkan bahwa kontribusi pendapatan tersebut sangat membantu keluarga pekerja dalam memenuhi kebutuhan keluarganya.

Selama masa pandemi covid-19 kontribusi usaha agroindustri tahu di Desa Kalisari Kecamatan Cilongok mengalami penurunan sebesar 0,19\%. Penurunan kontribusi usaha agroindustri tahu dibandingkan dengan penurunan tingkat pendapatan usaha agroindustri tahu yang mencapai $15,96 \%$ relatif kecil. Hal ini dapat dimengerti bahwa para pengrajin tetap berusaha untuk menjalankan usaha agroindustri tahu karena merupakan sumber penghasilan utama. Strategi yang dilakukan oleh para pengrajin untuk tetap bertahan di masa pandemi adalah dengan mengurangi produksinya mengingat terjadi kenaikan bahan baku. Untuk harga jual, para pengrajin tidak menaikan harga karena daya beli konsumen juga sedang mengalami penurunan, akan tetapi para pengrajin tahu mengurangi ukuran tahu menjadi lebih kecil. Sementara itu, terhadap kebijakan pemerintah yang membatasi aktivitas di luar rumah strategi bertahan yang dijalankan oleh para pengrajin tahu adalah melayani pembelian secara online (SMS maupun Whatsapp). Hasil penelitian ini sejalan dengan penelitian yang dilakukan oleh (Rukmana \& Sukanta, 2020), yang menjelaskan 
bahwa strategi bersaing dan bertahan yang dilakukan oleh industri mikro dan kecil di masa pandemi covid-19 adalah dengan melakukan pemasaran secara digital dan tidak melakukan kenaikan harga.

\section{KESIMPULAN DAN SARAN}

Berdasarkan hasil analisis data yang dilakukan diketahui bahwa biaya usaha agroindustri tahu di Desa Kalisari Kecamatan Cilongok mengalami penurunan antara sebelum dan selama masa pandemi covid-19. Penurunan biaya disebabkan karena pengrajin mengurangi jumlah produksinya yang berakibat pada penurunan pendapatan sebesar 15,96\%. Selama masa pandemi covid-19 berlangsung, kelayakan usaha agroindustri mengalami penurunan dari 1,57 menjadi 1,55. Penurunan kelayakan disebabkan karena terjadinya kenaikan harga utama bahan baku agroindustri tahu yaitu harga kedelai. Usaha agroindustri tahu di Desa Kalisari Kecamatan Cilongok memberikan kontribusi yang tinggi terhadap pendapatan rumah tangga pengrajin, walaupun terjadi penurunan kontribusi selama masa pandemi covid-19 dari 99,16\% menjadi 98,97\%.

Diperlukan upaya pendampingan selama masa pandemi covid-19 bagi para pengrajin dalam hal pemasaran terutama yang terkait dengan pemasaran digital. Selain itu diperlukan juga kebijakan pemerintah untuk tetap menjadi stabilitas harga bahan baku agroindustri tahu yaitu harga kedelai.

\section{DAFTAR PUSTAKA}

Alimul, H. (2010). Metode Penelitian Kesehatan Paradigma Kuantitatif. Health Book Publising Jakarta.

Anonim. (2019). Data Monografi Kantor Desa Kalisari Kecamatan Cilongok Kabupaten Banyumas. Desa Kalisari Kecamatan Cilongok Banyumas.

Bungin, B. (2005). Metodologi Penelitian Kuantitatif: Komunikasi, Ekonomi, dan Kebijakan Publik Serta Ilmu-ilmu Sosial Lainnya. Kencana Jakarta.

Ferdi. (2020). Dampak Pandemi Covid-19 Terhadap Aktivitas Ekonomi Masyarakat Di Desa Salumpaga, Kecamatan Tolitoli Utara. Geography Science Education Journal (GEOSEE), 1(2), 37-43.

Hadiwardoyo, W. (2020). Kerugian Ekonomi Nasional Akibat Pandemi Covid-19. Journal of Business and Entrepreneurship, 2(2), 83-92. https://doi.org/10.24853/baskara.2.2.83-92

Hasib, A. S. (2004). Analisis Sosial Ekonomi dan Kontribusi Agroindustri Biji Mete terhadap Pendapatan Keluarga. Jurusan Sosial Ekonomi Pertanian Universitas Jember, Jember.

Hirawan, F. B., \& Verselita, A. A. (2020). Kebijakan Pangan di Masa Pandemi. CSIS 


\section{Commentaries, April, 1-7.}

Kurniasih, E. P. (2020). Dampak Pandemi Covid 19 Terhadap Penurunan Kesejahteraan Masyarakat Kota Pontianak. Prosiding Seminar Akademik Tahunan Ilmu Ekonomi Dan Studi Pembangunan, 277-289.

Noor, B. S. M., Manginsela, E. P., \& Wangke, W. M. (2019). Kontribusi Pendapatan Pekerja Usaha Tahu Nipon Terhadap Pendapatan Keluarga Di Desa Tateli Kecamatan Mandolang Kabupaten Minahasa. Agri-SosioEkonomi, 15(1), 125-132.

Prakoso, J. P. (2021). Harga Kedelai Melonjak Jadi Catatan Merah Pemerintah di Awal 2021. Https://Ekonomi.Bisnis.Com/Read/20210106/12/1339386/Harga-KedelaiMelonjak-Jadi-Catatan-Merah-Pemerintah-Di-Awal-2021.

https://ekonomi.bisnis.com/read/20210106/12/1339386/harga-kedelai-melonjak-jadicatatan-merah-pemerintah-di-awal-2021

Riduwan. (2006). Metode dan Teknik Menyusun Tesis. Alfabeta, Bandung.

Rukmana, A. Y., \& Sukanta, T. A. (2020). Analisis Strategi Bersaing dan Strategi Bertahan pada Industri Mikro dan Kecil Panganan Keripik Kemasan di Kecamatan Coblong Kota Bandung Jawa Barat Tahun 2020 Ditengah Situasi Sulit Penyebaran Pandemi COVID-19. Jurnal Sains Manajemen \& Akuntansi, 12(1), 37-53.

Sarni, \& Sidayat, M. (2020). Dampak Pandemi Covid 19 terhadap Pendapatan Petani Sayuran di Kota Ternate. Prosiding Seminar Nasional Agribisnis, 144-148.

Setiawati, D., Istiyanti, E., \& Hasanah, U. (2013). Kontribusi Pendapatan Agroindustri Dawet Ireng Terhadap Pendapatan Keluarga Pengrajin Di Kecamatan Butuh Kabupaten Purworejo. Surya Agritama, 2(2), 13-22.

Sjarkowi, F., \& Sufri, M. (2004). Manajemen Agribisnis. CV Baldad Grafiti Press Palembang.

Soekartawi. (1995). Pembangunan Pertanian. PT. Raja Grafindo Persada, Jakarta.

Sugiyono. (2003). Metode Penelitian. Alfabeta, Bandung.

Udayana, I. G. B. (2011). Peran Agroindustri dalam Pembangunan Pertanian. Singhadwala, 44, 3-8. http://repository.warmadewa.ac.id/29/1/18-37-1-PB.pdf 